\title{
The heavy metals/trace elements contents of sediments from Owalla Reservoir, Osun State, Southwest Nigeria
}

\author{
Adedeji Idowu Aduwo, ${ }^{*}$ Israel Funso Adeniyi \\ Limnology and Hydrobiology Laboratory, Zoology Department, Obafemi Awolowo University, Ile-Ife, Osun State, Nigeria \\ *Corresponding author: anjiaduwo@gmail.com
}

\begin{abstract}
The heavy metals/trace elements contents of sediment samples from Owalla Reservoir were analyzed every three months in two annual cycles (March 2011 - February 2013). The main aim was to measure concentrations of selected elements in sediment samples, their variations in space and seasons and the level of pollution and/or contamination. The bottom sediment samples were collected with a Van Veen Grab and the elemental analysis in the laboratory was based on air-dried samples following standard methods. The overall hierarchy of heavy metals/trace elements in the sediments of the reservoir was in the decreasing order of concentrations: $\mathrm{Fe}>\mathrm{Mn}>\mathrm{As}$ $>\mathrm{Zn}>\mathrm{Ni}>\mathrm{Co}>\mathrm{Cr}>\mathrm{Cu}>\mathrm{Pb}>\mathrm{Cd}$. The concentrations of the heavy metals did not follow any definite pattern from the upstream-downstream basin, although most of them $(\mathrm{Cu}, \mathrm{Fe}, \mathrm{Mn}, \mathrm{Zn}$, and $\mathrm{Co})$ showed significant differences $(\mathrm{P}<0.05)$ in their horizontal variations. $\mathrm{Mn}, \mathrm{Pb}, \mathrm{Co}, \mathrm{Fe}, \mathrm{Ni}$, and $\mathrm{Zn}$ were significantly $(\mathrm{P}<0.05)$ higher at the open water region than in the littoral region. All the elements except Ni did not show significant seasonal variations $(\mathrm{P}>0.05)$. Most of the elements in the reservoir sediment have concentrations within the background levels and concentrations defined in environmental regulations and guidelines, except for As and Cd. The contamination factors $\left(\mathrm{C}_{\mathrm{f}}\right)$ for most metals $(\mathrm{Co}, \mathrm{Cr}, \mathrm{Cu}, \mathrm{Fe}, \mathrm{Mn}, \mathrm{Ni}, \mathrm{Pb}$, and $\mathrm{Zn})$ suggested low contamination in the sediments $\left(\mathrm{C}_{\mathrm{f}}<1.0\right)$. Conversely, the sediments were moderately contaminated with $\mathrm{Cd}\left(\mathrm{C}_{\mathrm{f}}=2.41\right)$ and very highly contaminated with $\mathrm{As}\left(\mathrm{C}_{\mathrm{f}}=19.33\right)$.
\end{abstract}

Key words: Anthropogenic; enrichments; pollution; grab; contamination factor; bioaccumulation; bottom sediment..

Received: May 2018. Accepted: December 2018.

\section{INTRODUCTION}

Heavy metals/trace elements are one of the major occurring constituents in sediments. Duffus (2002) suggested the densities of heavy metals range from 3.5 to $7.0 \mathrm{gcm}^{-3}$ (see also Gautam et al., 2015). However, since the threshold varies according to the author, it is impossible to come up with a precise consensus value. Therefore, any idea of defining "heavy metals" on the basis of density must be abandoned as it yields nothing but confusion (Duffus, 2002). An alternative (and theoretically more acceptable) name for this group of elements is "trace elements" but this is less widely used. Since heavy metals/trace elements occur naturally in rock-forming and ore minerals, there is a range of normal background concentrations in soil sediments, water and living organisms (Alloway and Ayres, 1997). Pollution causes a high abnormal concentration of metals/elements relative to the normal background levels. Therefore, the only presence of the metals/elements is insufficient evidence of pollution.

Heavy metals/trace elements are considered serious pollutants not only because of their persistence and nondegradability in the environment, but also because most of them have toxic effects on living organisms when they exceed certain concentrations. Additionally, aquatic organisms can bio-accumulate, bio-magnificate or bio-trans- fer metals to concentrations high enough to bring harmful effects (Raulinaitis et al. 2012).

Bottom sediment is the loose sand, clay, silt and other soil particles and organic matter that settle or deposit at the bottom of a water body. Sediments are originated from soil erosion (surface erosion in the watershed) or decomposition of plants, animals and microorganisms within the waterbody. Wind, water, and ice are erosion agents that help to carry these particles to streams, rivers and lakes (Davies and Abowei, 2009; Ezekiel et al., 2011). Sediments are a sink for many pollutants and trace substances of low solubility and low degree of degradability. Therefore, pollutants are conserved in sediments over a long period of time according to their chemical persistence, physical, chemical and biochemical characteristics of the sub-strata (Adeyemo et al., 2008). A large proportion of heavy metals/trace elements are originated and dispersed into the air and/or directly into rivers, lakes, sea and reservoirs (Todorovic et al., 2014) from anthropogenic activities such as industrial processes, mining, automobile emissions, agricultural activities, wastewater discharge, and urban runoff. Natural sources contributing to the presence of heavy metals in sediments include weathering and dissolution of minerals, parent rocks, and soils (Decena et al., 2018). Sediments can therefore act as natural geosorbent and primary sink for pollutants, including heavy 
metals/trace elements (Podlasinska and Szydlowski, 2017; Decena et al., 2018). High concentrations of these contaminants in sediments could be remobilized into the aquatic ecosystems through water and sediment interactions resulting in their bioaccumulation in the tissues of various biota, affecting the distribution and density of benthic organisms (Decena et al., 2018). Polluted aquatic sediments can also cause environmental damage by releasing metals/trace elements into the surrounding waters, directly contaminating aquatic plants and animals.

One of the most common methods for assessing pollution levels and quantifying metals and elemental enrichment in bottom sediments is to compare measured concentrations with a background level or with a concentration posing serious environmental risks (e.g. maximum concentration defined in environmental regulations and guidelines) usually referred to as Environmental Quality Standards (Raulinaitis et al. 2012). The geochemical background concentration is defined as the concentration of an element reflecting the natural processes not influenced by human activities. The discrimination between the natural and anthropogenic origin of heavy metals/trace elements is a relative measure that can be determined by the composition in the parent material. The geochemical background concentration allows the distinction of polluted areas from unpolluted ones and is useful for assessing the extent of human activities and the fate (i.e. mobilization, migration, and deposition/uptake of substances in the environment) of these elements. Furthermore, it also allows recognizing areas with the higher local background because of the occurrence of mineralization (Dung et al., 2013). Sediment Environmental Quality Standards are the "measuring stick" against which the acceptability of the presence and concentration of substances in sediment is determined. They help us better assess the quality of the sediment and how clean/healthy it could be. The environmental quality standards are based and designed to protect human and environmental health from the toxicological effects of contaminants (BCMECCS, 2017).

The aim of this study is to i) determine the concentrations of selected heavy metals/trace elements in sediment samples from Owalla Reservoir, ii) their variations in space and seasons, iii) the level of anthropogenic impact in the catchment basin, and iv) heavy metal/trace elements contamination, if any, in the reservoir.

\section{METHODS}

\section{Study area}

Owalla Reservoir is located within latitudes $07^{\circ} 53.5^{\prime}$ and $07^{\circ} 59.0^{\prime} \mathrm{N}$ and longitudes $004^{\circ} 31.5^{\prime}$ and $004^{\circ} 35.0^{\prime}$ E with an average elevation of $336 \pm 8 \mathrm{~m}$ above the mean sea level (Fig. 1). The reservoir is situated in the North of Osogbo, Osun State capital, about $35 \mathrm{~km}$ North of Ile-Ife, approximately $200 \mathrm{~km}$ North-East of Lagos, $360 \mathrm{~km}$ South-West of Abuja the capital city of Nigeria and bordered by Odo Otin, Ifelodun, Irepodun and Orolu Local Government Areas of Osun State at the northern, eastern, western and southern parts respectively. The dam wall is about $677 \mathrm{~m}$ long and $27.5 \mathrm{~m}$ high. The total length of the reservoir is about $12 \mathrm{~km}$ from the dam wall to the upstream (i.e. the point at which the major river, Erinle River, enters into the reservoir) with a maximum width of $3.5 \mathrm{~km}$. It has an area of about $14.5 \mathrm{~km}^{2}$ and capacity of about $94 \times 10^{6} \mathrm{~m}^{3}$.

The climate of the study area is typically tropical (Ojo, 1977). The area is underlain by the Basement Complex of Southwestern Nigeria (Kogbe, 1976; Rahaman, 1976; Rahaman and Ocan, 1978). Vegetation is the lowland tropical rainforest vegetation (Keay, 1959; Agboola, 1979; Tijani and Onodera, 2009). The soils belong to the Ferruginous tropical red soil (laterites) with minimal soil degradation and erosion (Smyth and Montgomery, 1962; Tijani and Onodera, 2009). The major source of heavy metals/trace elements around the study area could be originated from natural sources mostly by mineralization of parent rock materials. Anthropogenic sources are mainly from domestic and agricultural activities within the catchment basin. According to Oladejo and Ofoezie (2006) and Ugbomoiko and Ofoezie (2007), the municipalities surrounding the reservoir (i.e. Ilie, Oba, Bara, Onipakiti, Kuti, Igbokiti, Idiroko, Eko-Ende, and Ore, etc.) have a population of less than 5000 persons each, with an annual growth rate of about $3 \%$. The inhabitants are mostly Yoruba, many of whom are peasant farmers, fishermen or petty traders in agricultural goods. There is no evidence of heavy industrialization. Riparian vegetation of the area includes cultivated crops such as vegetables, cashew, mango, cocoa, kola nut, oranges, oil palm, cassava, yam, maize, banana and plantain.

\section{Sampling stations and programme}

A total of twenty (20) sampling stations were established across the entire reservoir, representing three different sections (upstream, mid-basin and downstream) and two zones (littoral and open water) (Fig. 1; Supplementary Tab. 1). Sampling was carried out every three months aboard a plank boat powered by an outboard-engine in two annual cycles (March 2011 - February 2013).

\section{Sample collections/field determination and laboratory analysis}

A Van-Veen Grab of $0.04 \mathrm{~m}^{2}$ area $(0.2 \mathrm{~m} \times 0.2 \mathrm{~m})$ was used to collect the bottom sediments for the elemental analysis. Samples were taken and kept in a labeled poly- 
thene bag for laboratory analysis of the heavy metal/trace elements contents of the sediments and analysis of the elements in the sediments was based on air-dried samples, dried in clean trays at room temperature. The laboratory analyses of the heavy metals/trace elements were done using the Atomic Absorption Spectrophotometry (AAS) (APHA, 1995; International Atomic Energy Agency, 2003; Supplementary Tab. 2). Adequate and proper quality control and quality assurance $(\mathrm{QA} / \mathrm{QC})$ measures were observed both at the field and during the laboratory analysis to ensure accurate results and reliability of the data obtained following the appropriate Standard Methods and Instructions. The data obtained were analysed computing descriptive statistics, analysis of variance-ANOVA, and Cluster Analysis using Microsoft Excel and Paleontological Statistics (PAST, ver. 3.17) software. Cluster analysis was computed using the correlation index and the paired group method.

\section{Calculation of the contamination factor of the heavy metals/trace elements}

The contamination factor $\left(\mathrm{C}_{\mathrm{f}}\right)$ is an indicator of sediment contamination used in evaluating pollution in an aquatic environment by a given toxic substance (Decena et al., 2018). The contamination factor and the degree of contamination $\left(\mathrm{C}_{\mathrm{d}}\right)$ of the heavy metals/trace elements analyzed for the study were used to determine the contamination status of sediments. The $C_{f}$ values for each metal/element based on their overall average values from all the stations in the reservoir were calculated according to the equation given below:

\section{Contamination factor $\left(\mathbf{C}_{\mathrm{f}}\right)=$ Metal/element content of sediment Background value of the metal/element}

Where the background value of the metal/element $=$ world surface rock average (Geochemical background in the earth crust).

$\mathrm{C}_{\mathrm{f}}$ values for describing the contaminations level of the heavy metals/trace elements in the sediment according to Saha and Hossain (2011) are as given below:

\section{$\mathrm{C}_{\mathrm{f}}<1$ \\ $1 \leq \mathrm{C}_{\mathrm{f}}<3$ \\ $3 \leq \mathrm{C}_{\mathrm{f}}<6$ \\ $\mathrm{C}_{\mathrm{f}}>6$}

Contamination factor
A

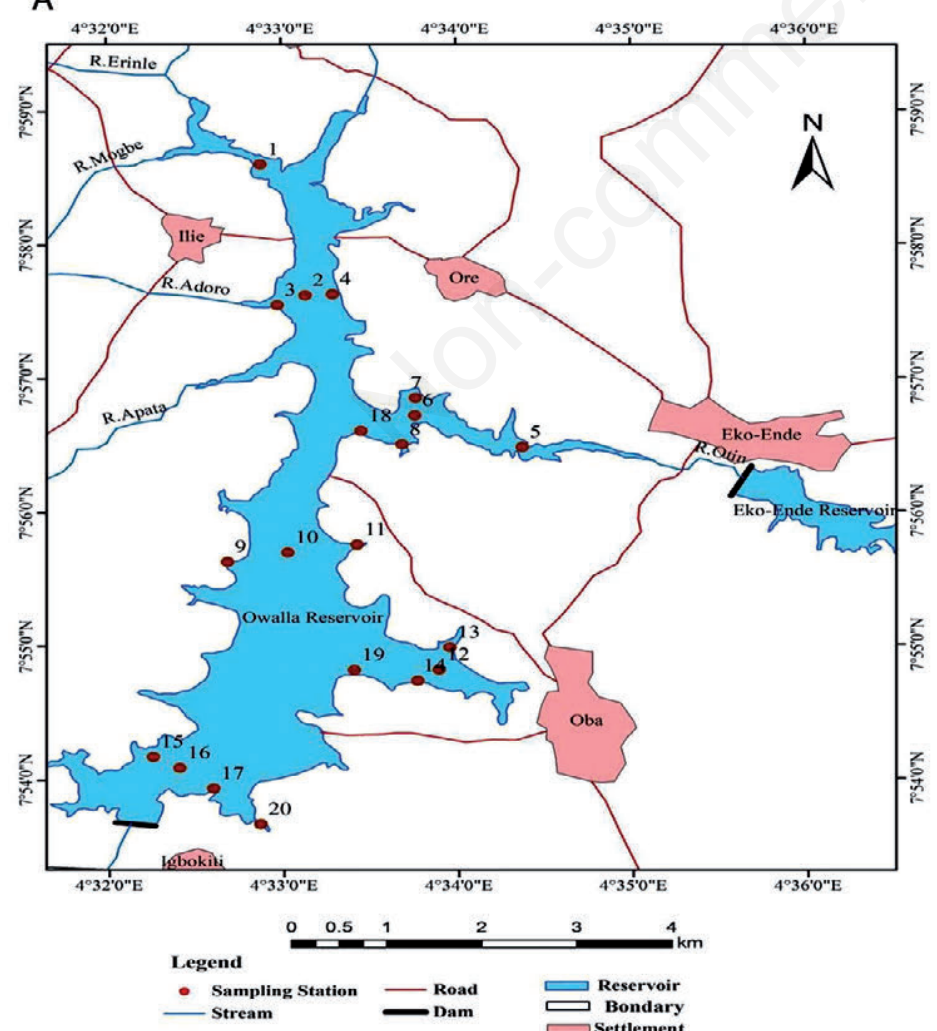

B
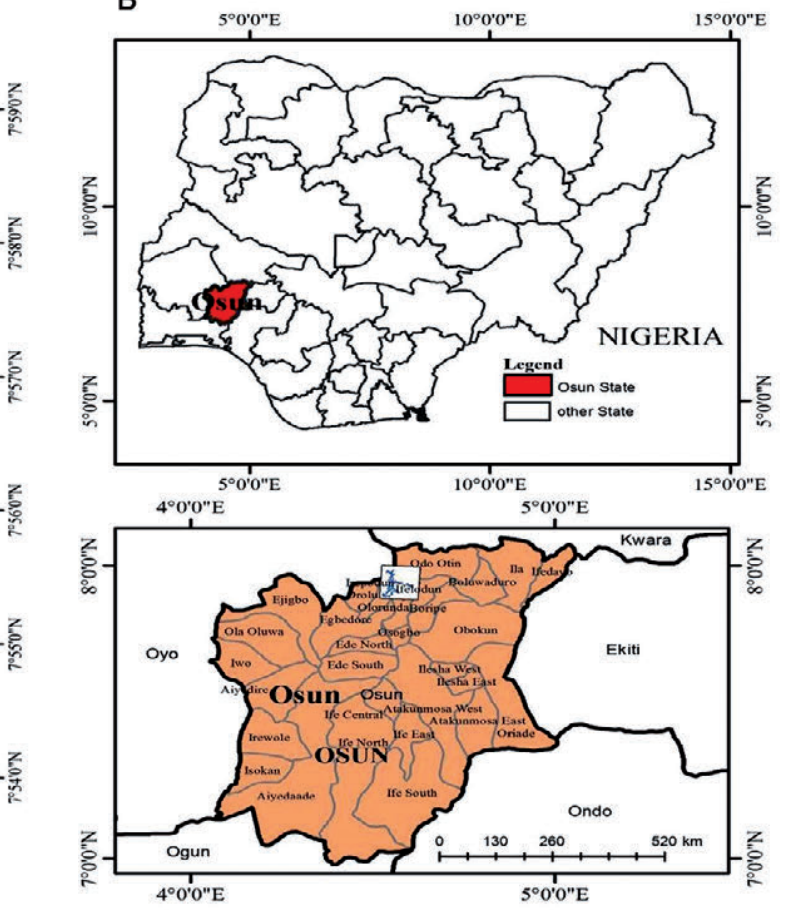

Osun State showing the Local Government Areas

Fig. 1. A) Lake Map and (numbers from 1 to 20) sampling stations. Upper reach: stations 1-4; mid-basin: 5-11, 18; lower reach: 12-17, 19-20. littoral, 3-4, 7-9, 11, 13-15, 17-20; open water, 1-2, 5-6, 10, 12, 16. B) Map of the study area. 
The degree of contamination $\left(\mathrm{C}_{\mathrm{d}}\right)$ is defined as the sum of all contamination factors $\left(\mathrm{C}_{\mathrm{f}}\right)$ for all the metals studied in the given waterbody.

\section{RESULTS}

\section{Overall variations in Owalla Reservoir}

The concentrations of the individual heavy metals/trace elements in the reservoir occurred over the wide range of $0.00-377.41 \mu \mathrm{g} \mathrm{g}^{-1}$ (Tab. 1). Based on the mean values, they could be grouped into two categories, i.e.:

$$
\begin{aligned}
& <100 \mu \mathrm{g} \mathrm{g}^{-1=} \mathrm{As}>\mathrm{Zn}>\mathrm{Ni}>\mathrm{Co}>\mathrm{Cr}>\mathrm{Cu}>\mathrm{Pb}>\mathrm{Cd} \\
& >100 \mu \mathrm{g} \mathrm{g}^{-1}=\mathrm{Fe}>\mathrm{Mn}
\end{aligned}
$$

\section{Comparison with other reservoirs and lakes}

Heavy metals/trace elements in sediments recorded in the present study showed marked similarities with the mass concentrations and hierarchy obtained in some reservoirs in Nigeria and other parts of the world (Tab. 2).

\section{Contamination factor and comparison with toxicological reference values}

In Tab. 3 , contamination factors $\left(\mathrm{C}_{\mathrm{f}}\right)$ were computed as the ratio between the concentrations of trace elements in the Owalla Reservoir and the corresponding average concentrations in the Earth crust. The degree of contamination, $\mathrm{C}_{\mathrm{d}}$, was 22.72. The maximum $\mathrm{C}_{\mathrm{f}}, 19.33$, was estimated for cadmium and the least, 0.003, for iron. Excluding As, the remaining elements, i.e. $\mathrm{Co}, \mathrm{Cr}, \mathrm{Cu}, \mathrm{Fe}, \mathrm{Mn}, \mathrm{Ni}, \mathrm{Pb}$, and $\mathrm{Zn}$ had $\mathrm{C}_{\mathrm{f}}<1$ (Table 3). Most of the heavy metals/trace elements in the sediments showed concentrations within the background levels and guidelines, with the exception of As and $\mathrm{Cd}$, which concentrations were greater than the geochemical background level. Moreover, As concentration was greater than the Canadian Guidelines. Cd value was greater than the values for all the guidelines (i.e. UK-Cefas, Dutch Standard, Canadian Guidelines, and US Environmental Protection Agency).

\section{Spatial variations}

The $\mathrm{Co}, \mathrm{Cr}$ and $\mathrm{Fe}$ contents of the reservoir sediment had highest mean values upstream and decreased through the middle portion of the reservoir and towards the dam site (Table 4). The lowest values were recorded at the downstream basin. Mn showed lowest mean values upstream and increased through the middle portion of the reservoir and downstream. $\mathrm{As}, \mathrm{Cd}, \mathrm{Cu}, \mathrm{Ni}, \mathrm{Pb}$, and $\mathrm{Zn}$ showed highest mean values at the middle area of the reservoir; $\mathrm{Cd}$ and $\mathrm{Ni}$ had lowest mean values upstream, whereas $\mathrm{As}, \mathrm{Cu}, \mathrm{Pb}$, and $\mathrm{Zn}$ had lowest values downstream.

$\mathrm{Co}, \mathrm{Cu}, \mathrm{Fe}, \mathrm{Mn}$, and $\mathrm{Zn}$ showed significant differences $(\mathrm{P} \leq 0.05)$ in their mean values along the (upstream-downstream) reaches of the reservoir, whereas the other metals/elements were not significantly different $(\mathrm{P}>0.05)$ (Tab. 4). All the heavy/trace metals analysed from the sediment samples collected throughout the study period showed higher mean values at the open water region than in the littoral region of the reservoir (Tab. 5). Differences were significant $(\mathrm{P}<0.05)$ for $\mathrm{Co}, \mathrm{Fe}, \mathrm{Mn}, \mathrm{Ni}, \mathrm{Pb}$, and $\mathrm{Zn}$ (Tab. 5).

The relationships among the investigated sampling stations based on the concentrations of the metals/elements in the sediments have been analysed using a cluster analysis (Fig. 2). Heavy metal concentrations grouped the stations into five clusters. Nevertheless, the grouping of stations did not follow any definite and congruent spatial pattern, confirming the absence of any spatial patterns also in the concentrations of the heavy metals/trace elements.

\section{Seasonal variations}

$\mathrm{As}, \mathrm{Cd}, \mathrm{Cu}, \mathrm{Ni}, \mathrm{Pb}$, and $\mathrm{Zn}$ had higher mean values during the rainy season than the dry season. On the contrary,

\begin{tabular}{|c|c|c|c|c|c|c|c|c|c|c|c|}
\hline \multirow[b]{2}{*}{$\mathbf{S} / \mathbf{N}$} & \multirow[b]{2}{*}{ Parameter } & \multirow[b]{2}{*}{ Unit } & \multicolumn{9}{|c|}{ Descriptive statistics } \\
\hline & & & $\mathbf{N}$ & Min & Max & Mean & Median & SEM & SD & Skewness & Kurtosis \\
\hline 1 & Arsenic (As) & $\mu \mathrm{g} \mathrm{g}^{-1}$ & 152 & 0.07 & 37.16 & 12.06 & 11.40 & 0.48 & 5.91 & 1.31 & 5.14 \\
\hline 2 & Cadmium (Cd) & $\mu \mathrm{g} \mathrm{g}^{-1}$ & 152 & 1.85 & 3.44 & 2.90 & 2.91 & 0.02 & 0.23 & -2.17 & 8.67 \\
\hline 3 & Cobalt (Co) & $\mu \mathrm{g} \mathrm{g}^{-1}$ & 152 & 2.77 & 20.78 & 6.81 & 6.30 & 0.24 & 2.90 & 1.50 & 3.38 \\
\hline 4 & Chromium (Cr) & $\mu \mathrm{g} \mathrm{g}^{-1}$ & 152 & 1.47 & 8.63 & 3.88 & 3.39 & 0.15 & 1.85 & 0.46 & -0.98 \\
\hline 5 & Copper $(\mathrm{Cu})$ & $\mu \mathrm{g} \mathrm{g}^{-1}$ & 152 & 0.03 & 32.20 & 3.19 & 2.33 & 0.27 & 3.39 & 4.37 & 33.02 \\
\hline 6 & Iron $(\mathrm{Fe})$ & $\mu \mathrm{g} \mathrm{g}^{-1}$ & 152 & 41.99 & 377.41 & 176.22 & 181.51 & 4.40 & 54.27 & 0.26 & 1.02 \\
\hline 7 & Manganese (Mn) & $\mu \mathrm{g} \mathrm{g}^{-1}$ & 152 & 23.05 & 189.88 & 120.46 & 128.55 & 2.96 & 36.51 & -0.59 & -0.40 \\
\hline 8 & Nickel (Ni) & $\mu \mathrm{g} \mathrm{g}^{-1}$ & 152 & 0.50 & 18.58 & 7.26 & 6.77 & 0.27 & 3.27 & 0.96 & 1.22 \\
\hline 9 & Lead $(\mathrm{Pb})$ & $\mu \mathrm{g} \mathrm{g}^{-1}$ & 152 & 0.00 & 10.70 & 3.05 & 2.18 & 0.22 & 2.73 & 0.89 & -0.16 \\
\hline 10 & Zinc (Zn) & $\mu \mathrm{g} \mathrm{g}^{-1}$ & 152 & 0.00 & 45.51 & 8.99 & 4.69 & 0.72 & 8.90 & 1.11 & 1.00 \\
\hline
\end{tabular}

Tab. 1. Descriptive statistics of the concentrations of heavy metals/trace elements from the Owalla Reservoir sediment samples. 
$\mathrm{Co}, \mathrm{Cr}, \mathrm{Fe}$, and $\mathrm{Mn}$ had higher mean values during the dry season than the rainy season. Nevertheless, only Ni showed significant seasonal differences $(\mathrm{P}<0.05)$ (Tab. 6).

\section{DISCUSSION}

The similarities in the heavy metals/trace elements content recorded from the present study with the levels obtained for some reservoirs in Nigeria and other parts of the world with respect to mass concentrations and hierarchy is an evidence of their natural occurrence in rockforming and ore minerals soil and sediments globally. However, the variations observed in a few elements from the selected reservoirs could be ascribed to the nature of the catchment basin and the underlying bedrock geology of the area and the type of anthropogenic activities around the basin. For example, land use pattern is recognized as a crucial factor influencing the concentrations of these elements in terrestrial and aquatic environments in various regions of the world (Szarek-Gwiazda et al., 2018). Unlike most organic pollutants, such as organo-halides, heavy metals occur naturally in a range of normal background concentrations in soil sediments, water and living organisms (Alloway and Ayres, 1997). Pollution gives rise to an anomalously high concentration of metals relative to the normal background levels. Therefore, the presence of metals may not be a sufficient evidence of pollution. However, several countries have set Environmental Quality Standard (EQS) or background levels of metals in sediment. Such interim guidelines are basically designed for soil and sediment remediation with a wide range of pollutants including, but not limited to, metals (Asibor, 2008). The concentrations of most of the heavy metals/trace elements from the present study were generally lower than the geochemical background level (earth crust) representing the world average concentrations of the metals in sediments. Exceptions were Arsenic (As) and Cadmium $(\mathrm{Cd})$ that were present with higher average values in the reservoir. Asibor (2008) suggested that one

Tab. 2. Comparison of the heavy metals/trace elements average concentrations $(\mu \mathrm{g} g-1)$ in sediments from reservoirs and lakes in Nigeria and other countries around the world, and the present study.

\begin{tabular}{|c|c|c|c|c|c|c|c|c|c|c|c|c|c|}
\hline & Reserve & r/Lake & & & & & $\mathbf{M}$ & tals & & & & & \\
\hline $\mathbf{S} / \mathbf{N}$ & Name & Location & As & Cd & Co & $\mathrm{Cr}$ & $\mathbf{C u}$ & $\mathrm{Fe}$ & Mn & $\mathbf{N i}$ & $\mathbf{P b}$ & $\mathbf{Z n}$ & Reference \\
\hline 1 & Opa & Nigeria & - & - & - & - & 12.28 & 2523.87 & 1137.03 & - & 0.32 & 55.68 & Nathaniel, 2002 \\
\hline 2 & Opa & Nigeria & - & - & - & 183.00 & - & 67468.22 & 2525.89 & - & 140.00 & 155.67 & Ogunkoya, 2013 \\
\hline 3 & Aiba & Nigeria & - & - & - & - & 5.82 & 42.03 & 28.00 & - & 0.44 & 11.91 & Olutona et al., 2012 \\
\hline 4 & Asejire & Nigeria & - & - & - & 0.03 & 43.50 & 39873.00 & 1.52 & 0.05 & 71.9 & 20.80 & Asibor, 2008 \\
\hline 5 & Awassa & Ethiopia & - & - & 5.49 & 8.27 & 8.69 & - & - & 20.20 & 15.70 & 93.80 & Yohannes et al., 2013* \\
\hline 6 & Owabi & Ghana & - & - & - & - & 0.03 & 4.03 & - & - & 0.10 & 0.40 & Akot and Abankwa, 2014 \\
\hline 7 & Nasser & Egypt & - & - & 113.60 & 158.30 & 59.90 & - & 784.00 & - & 86.60 & 119.10 & Lasheen, 1987 \\
\hline 8 & Nasser & Egypt & - & 0.18 & - & 30.79 & 21.78 & 12418.00 & 279.60 & 27.56 & 10.91 & 35.38 & Goher et al., 2014 \\
\hline 9 & Mariut & Egypt & - & - & - & - & 38.0 & 25600.00 & 958.00 & - & 7.30 & 94.00 & Biney et al., 1994**** \\
\hline 10 & Nubia & Sudan & - & - & 131.9 & 332.6 & 54.7 & - & 1196.00 & - & 79.40 & 138.80 & Lasheen, 1987 \\
\hline 11 & Victoria & Tanzania & 4.74 & 1.34 & - & - & 24.13 & - & - & - & 22.98 & 105.85 & Machiwa, 2003 \\
\hline 12 & Masinga & Kenya & - & - & - & 33.06 & 17.31 & - & 525.25 & - & 12.71 & 68.51 & Nzeve et al., 2014 \\
\hline 13 & Yilong & China & - & - & - & 86.73 & 31.40 & - & - & 35.99 & 53.19 & 86.82 & Bai et al., 2011* \\
\hline 14 & Dongting & China & 29.71 & 4.65 & - & 88.29 & 47.48 & - & - & - & 60.99 & 185.25 & Li et al., 2013 \\
\hline 15 & Texoma & USA & - & - & 9.00 & 30.00 & 38.00 & - & - & 17.00 & 10.00 & 89.00 & An et al., 2003* \\
\hline 16 & Erie & USA & - & 3.60 & - & 64.90 & 34.30 & - & - & - & 98.70 & 162.60 & Opfer et al., 2011** \\
\hline 17 & Manchar & Pakistan & - & - & 4.70 & 20.00 & 21.00 & - & - & 20.10 & 18.90 & 96.60 & Arain et al., 2008* \\
\hline 18 & Veeranam & India & - & - & - & 88.20 & 94.12 & - & - & 63.61 & 30.06 & 180.08 & Suresh et al., 2012* \\
\hline 19 & Laguna & Philippines & - & - & - & 16.90 & 103.00 & - & - & 13.00 & 20.00 & 13.50 & Hallare et al., 2005* \\
\hline 20 & Karla & Greece & - & - & 27.40 & 298.40 & 38.30 & - & - & 182.80 & 34.30 & 31.20 & Skordas et al., 2015 \\
\hline 21 & Kariba & Zimbabwe & - & 0.06 & - & 29.30 & 16.10 & - & - & - & 9.40 & 42.40 & Kishe and Machiwa, 2003** \\
\hline 22 & Itá & Brazil & - & 6.33 & - & 90.27 & 179.86 & 105301.94 & 2265.12 & - & 20.57 & 232.04 & Bonai et al., 2009 \\
\hline 23 & Wallace & Australia & - & 2.61 & 28.00 & 28.00 & 162.13 & 2.58 & 327.25 & 51.25 & 29.88 & 446.25 & Birch et al., 2001 \\
\hline 24 & Trasimeno & Italy & 9.00 & - & - & 71.70 & 22.30 & 30004.00 & 1566.00 & 49.00 & 20.60 & 59.10 & Baudo and Muntau, 1986*** \\
\hline 25 & European L & kes (Average & e) - & 2.41 & - & 142.00 & 96.00 & 33300.00 & 2336.00 & 66.00 & 135.00 & 1082.00 & Morgantini and Peruzzi, 2014 \\
\hline 26 & World Aver & & - & - & - & 90.00 & 45.00 & 47000.00 & 850.00 & - & 20.00 & 95.00 & Filho et al., 2015 \\
\hline 27 & Owalla & Nigeria & 12.06 & 2.90 & 6.81 & 3.88 & 3.19 & 176.22 & 120.46 & 7.26 & 3.05 & 8.99 & This Study \\
\hline
\end{tabular}

*Cited by Skordas et al., 2015; **cited by Jahangir et al., 2014; ***cited by Morgantini and Peruzzi, 2014; ****cited by Asibor, 2008. 
Tab. 3. Concentrations of heavy metals/trace elements in Owalla Reservoir, geochemical background levels and the toxicological reference values of the metals in river and lake sediments. Concentrations expressed as $\mu \mathrm{g} \mathrm{g}^{-1}$.

\begin{tabular}{|c|c|c|c|c|c|c|c|c|c|c|c|c|c|}
\hline \multirow{2}{*}{$\mathbf{S} / \mathbf{N}$} & \multirow{2}{*}{ Metal } & \multicolumn{2}{|c|}{ This study } & \multicolumn{2}{|c|}{ Geochemical background } & \multicolumn{2}{|c|}{ UK-Cefas ${ }^{A}$} & \multicolumn{2}{|c|}{ Dutch Std. ${ }^{A}$} & \multicolumn{2}{|c|}{ Canadian Gdls. $^{A}$} & \multirow{2}{*}{ US-EPA $^{\mathrm{c}}$} & \multirow{2}{*}{ TLES $^{d}$} \\
\hline & & Value & $\mathbf{C}_{\mathrm{f}}$ & Earth crust ${ }^{\mathrm{a}}$ & Shale ${ }^{\mathrm{b}}$ & $\mathbf{A} \mathbf{L}^{-1}$ & $\mathbf{A} \mathbf{L}^{-2}$ & TV & RV & TEL & PEL & & \\
\hline 1 & As & 12.06 & 2.41 & $5.00 * *$ & - & 20.00 & 100.00 & 29.00 & 55.00 & 7.24 & 41.60 & - & 5.90 \\
\hline 2 & $\mathrm{Cd}$ & 2.90 & 19.33 & 0.15 & 0.30 & 0.40 & 5.00 & 0.80 & 7.50 & 0.70 & 4.20 & 0.60 & 0.60 \\
\hline 3 & Co & 6.81 & 0.27 & $25.00^{*}$ & - & - & - & - & - & - & - & - & - \\
\hline 4 & $\mathrm{Cr}$ & 3.88 & 0.04 & 100.00 & 90.00 & 40.00 & 400.00 & 100.00 & 380.00 & 52.30 & 160.00 & 26.00 & 37.30 \\
\hline 5 & $\mathrm{Cu}$ & 3.19 & 0.06 & 55.00 & 40.00 & 40.00 & 400.00 & 35.00 & 90.00 & 18.70 & 108.00 & 16.00 & 35.70 \\
\hline 6 & $\mathrm{Fe}$ & 176.22 & 0.003 & 56300.00 & 46700.00 & - & - & - & - & - & - & - & - \\
\hline 7 & $\mathrm{Mn}$ & 120.46 & 0.14 & 850.00 & 950.00 & - & - & - & - & - & - & - & 460.00 \\
\hline 8 & $\mathrm{Ni}$ & 7.26 & 0.10 & 75.00 & 68.00 & 20.00 & 200.00 & 35.00 & 45.00 & 15.90 & 42.80 & 16.00 & 18.00 \\
\hline 9 & $\mathrm{~Pb}$ & 3.05 & 0.24 & 12.50 & 20.00 & 50.00 & 500.00 & 85.00 & 530.00 & 30.00 & 112.00 & 31.00 & 35.00 \\
\hline 10 & $\mathrm{Zn}$ & 8.99 & 0.13 & 70.00 & 95.00 & 130.00 & 800.00 & 140.00 & 720.00 & 124.00 & 271.00 & 110.00 & 123.00 \\
\hline
\end{tabular}

UK-Cefas, United Kingdom Centre for Environment Fisheries and Aquaculture Science; Dutch Std., Dutch standards; Canadian Gdls, Canadian guidelines; AL-1, action level 1 (contaminants below this level are of no concern/unlikely to influence licensing decision); AL-2, action level 2 (contaminants above this level are considered unsuitable for the environment); TV, target value (target below which the risk to the environment are considered to be negligible); $\mathrm{RV}$, reference value (maximum allowable level, above which the risks to the environment are unacceptable); TEL, threshold effect level (exposure to this level is likely to affect some sensitive species); PEL, probable effect level (exposure to this level is likely to cause an adverse effect to a wider range of species); US-EPA, United State Environmental Protection Agency; TLES, threshold level effect in sediments; ${ }^{\mathrm{A} E S P S}, 2015 ;{ }^{\mathrm{a}}$ Turekian and Wedepohl, 1961;

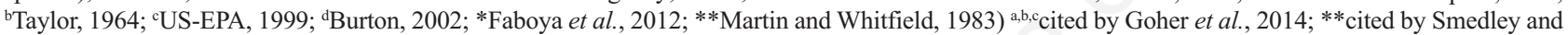
Kinniburgh, 2002.

Tab. 4. Variations of heavy metals/trace elements concentrations in sediments along the major axis of Owalla Reservoir.

\begin{tabular}{|c|c|c|c|c|c|c|c|}
\hline & & & & Reach & & & \\
\hline & & & Upstream & Mid-basin & Downstream & & \\
\hline $\mathbf{S} / 1$ & Parameter & Unit & Mean \pm SE & Mean $\pm \mathbf{S E}$ & Mean \pm SE & F & $\mathbf{P}$ \\
\hline & avy/trace metal co & f sediment & $(\mathrm{N}=32)$ & $(\mathrm{N}=90)$ & $(\mathbf{N}=\mathbf{3 0})$ & & \\
\hline 1 & Arsenic (As) & $\mu \mathrm{g} \mathrm{g}^{-1}$ & $11.33 \pm 0.74$ & $12.64 \pm 0.71$ & $11.12 \pm 0.86$ & 1.049 & 0.353 \\
\hline 2 & Cadmium $(\mathrm{Cd})$ & $\mu \mathrm{g} \mathrm{g}^{-1}$ & $2.82 \pm 0.07$ & $2.92 \pm 0.02$ & $2.91 \pm 0.02$ & 2.275 & 0.106 \\
\hline 3 & Cobalt (Co) & $\mu \mathrm{g} \mathrm{g}^{-1}$ & $8.02 \pm 0.67$ & $6.82 \pm 0.28$ & $5.53 \pm 0.31$ & 6.070 & $0.003^{*}$ \\
\hline 4 & Chromium (Cr) & $\mu \mathrm{g} \mathrm{g}^{-1}$ & $4.34 \pm 0.38$ & $3.79 \pm 0.18$ & $3.69 \pm 0.35$ & 1.275 & 0.282 \\
\hline 5 & Copper $(\mathrm{Cu})$ & $\mu \mathrm{g} \mathrm{g}^{-1}$ & $3.07 \pm 0.41$ & $3.66 \pm 0.42$ & $1.90 \pm 0.30$ & 3.161 & $0.045^{*}$ \\
\hline 6 & Iron $(\mathrm{Fe})$ & $\mu \mathrm{g} \mathrm{g}^{-1}$ & $193.48 \pm 11.39$ & $175.52 \pm 5.02$ & $159.89 \pm 10.54$ & 3.065 & $0.050^{*}$ \\
\hline 7 & Manganese (Mn) & $\mu \mathrm{g} \mathrm{g}^{-1}$ & $104.92 \pm 6.00$ & $123.23 \pm 3.90$ & $128.73 \pm 6.20$ & 4.085 & $0.019 *$ \\
\hline 8 & Nickel (Ni) & $\mu \mathrm{g} \mathrm{g}^{-1}$ & $6.69 \pm 0.55$ & $7.55 \pm 0.34$ & $7.00 \pm 0.67$ & 0.939 & 0.393 \\
\hline 9 & Lead $(\mathrm{Pb})$ & $\mu \mathrm{g} \mathrm{g}^{-1}$ & $3.22 \pm 0.43$ & $3.24 \pm 0.30$ & $2.27 \pm 0.49$ & 1.509 & 0.225 \\
\hline 10 & Zinc (Zn) & $\mu \mathrm{g} \mathrm{g}^{-1}$ & $8.79 \pm 1.45$ & $10.33 \pm 1.02$ & $5.21 \pm 1.04$ & 3.863 & $0.023^{*}$ \\
\hline
\end{tabular}

Degree of freedoms, between groups: 2 ; within groups: $149 ;{ }^{*} \mathrm{P} \leq 0.05$.

Tab. 5. Horizontal variations of the heavy metals/trace elements concentrations in the sediments across the major axis of Owalla Reservoir.

\begin{tabular}{|c|c|c|c|c|c|c|}
\hline & & & & & & \\
\hline & & & Open-Water & Littoral & & \\
\hline $\mathbf{S} / \mathbf{N}$ & Parameter & Unit & Mean $\pm \mathrm{SE}$ & Mean $\pm \mathbf{S E}$ & $\mathbf{F}$ & $\mathbf{P}$ \\
\hline Hes & vy/trace metal co & f sediment & $(\mathrm{N}=56)$ & $(\mathrm{N}=96)$ & & \\
\hline 1 & Arsenic (As) & $\mu \mathrm{g} \mathrm{g}^{-1}$ & $12.10 \pm 0.72$ & $12.04 \pm 0.63$ & 0.004 & 0.953 \\
\hline 2 & Cadmium $(\mathrm{Cd})$ & $\mu \mathrm{g} \mathrm{g}^{-1}$ & $2.91 \pm 0.04$ & $2.89 \pm 0.02$ & 0.506 & 0.478 \\
\hline 3 & Cobalt (Co) & $\mu \mathrm{g} \mathrm{g}^{-1}$ & $8.29 \pm 0.46$ & $5.95 \pm 0.21$ & 26.780 & $7.189 \times 10^{-7 *}$ \\
\hline 4 & Chromium (Cr) & $\mu \mathrm{g} \mathrm{g}^{-1}$ & $4.22 \pm 0.25$ & $3.69 \pm 0.19$ & 2.932 & 0.089 \\
\hline 5 & Copper $(\mathrm{Cu})$ & $\mu \mathrm{g} \mathrm{g}^{-1}$ & $3.52 \pm 0.31$ & $3.00 \pm 0.40$ & 0.831 & 0.364 \\
\hline 6 & Iron $(\mathrm{Fe})$ & $\mu \mathrm{g} \mathrm{g}^{-1}$ & $197.54 \pm 6.28$ & $163.78 \pm 5.57$ & 14.950 & $1.640 \times 10^{-4 *}$ \\
\hline 7 & Manganese (Mn) & $\mu \mathrm{g} \mathrm{g}^{-1}$ & $131.06 \pm 4.63$ & $114.27 \pm 3.71$ & 7.818 & $0.006^{*}$ \\
\hline 8 & Nickel (Ni) & $\mu \mathrm{g} \mathrm{g}^{-1}$ & $8.49 \pm 0.52$ & $6.54 \pm 0.26$ & 13.660 & $3.06 \times 10^{-4 *}$ \\
\hline 9 & Lead $(\mathrm{Pb})$ & $\mu \mathrm{g} \mathrm{g}^{-1}$ & $3.81 \pm 0.38$ & $2.60 \pm 0.26$ & 7.338 & $0.008^{*}$ \\
\hline 10 & Zinc (Zn) & $\mu \mathrm{g} \mathrm{g}^{-1}$ & $12.60 \pm 1.34$ & $6.89 \pm 0.76$ & 15.96 & $1.01 \times 10^{-4 *}$ \\
\hline
\end{tabular}

Degree of freedoms, between groups: 1 ; within groups: $150 ; * \mathrm{P} \leq 0.05$. 
of the main reasons of the low metals concentrations he observed in the sediments of Asejire reservoir was the low level of industrialization within the catchment basin. On the other hand, Kavitha and Kumar (2013) associated the accumulation of heavy metals in the sediments and biota of receiving waterbodies to rapid industrialization, urbanization, modern civilization, economic development and increase in population. According to Smedley and Kinniburgh (2015), Arsenic is a ubiquitous element found in the atmosphere, soils, rocks, natural waters, and organisms. It is mobilized in the environment through a combination of natural processes such as weathering reactions, biological activity, and volcanic emissions as well as through a range of anthropogenic activities. Most environmental arsenic problems are the result of mobilization under natural conditions, but man has an important impact through mining activity, combustion of fossil fuels, the use of arsenical pesticides, herbicides and crop desiccants and the use of arsenic as an additive to livestock feed, particularly for poultry.

From the study area, some of the likely sources of the elevated levels of arsenic may include natural enrichment. The typical richness of arsenic in the Earth's crust is between approximately 2 and $5 \mathrm{mg} \mathrm{kg}^{-1}$. However, an enriched amount may be found in shale and coal deposits of sedimentary and igneous rocks. Arsenic adsorption to mineral surfaces (including Fe, Mn, and Al-rich soil and sediments) act as an important sink. Arsenic exists mainly in the atmosphere in various forms such as $\left(\mathrm{As}_{2} \mathrm{O}\right)$ adsorbed on particulate matter, which circulates and is returned to the Earth by

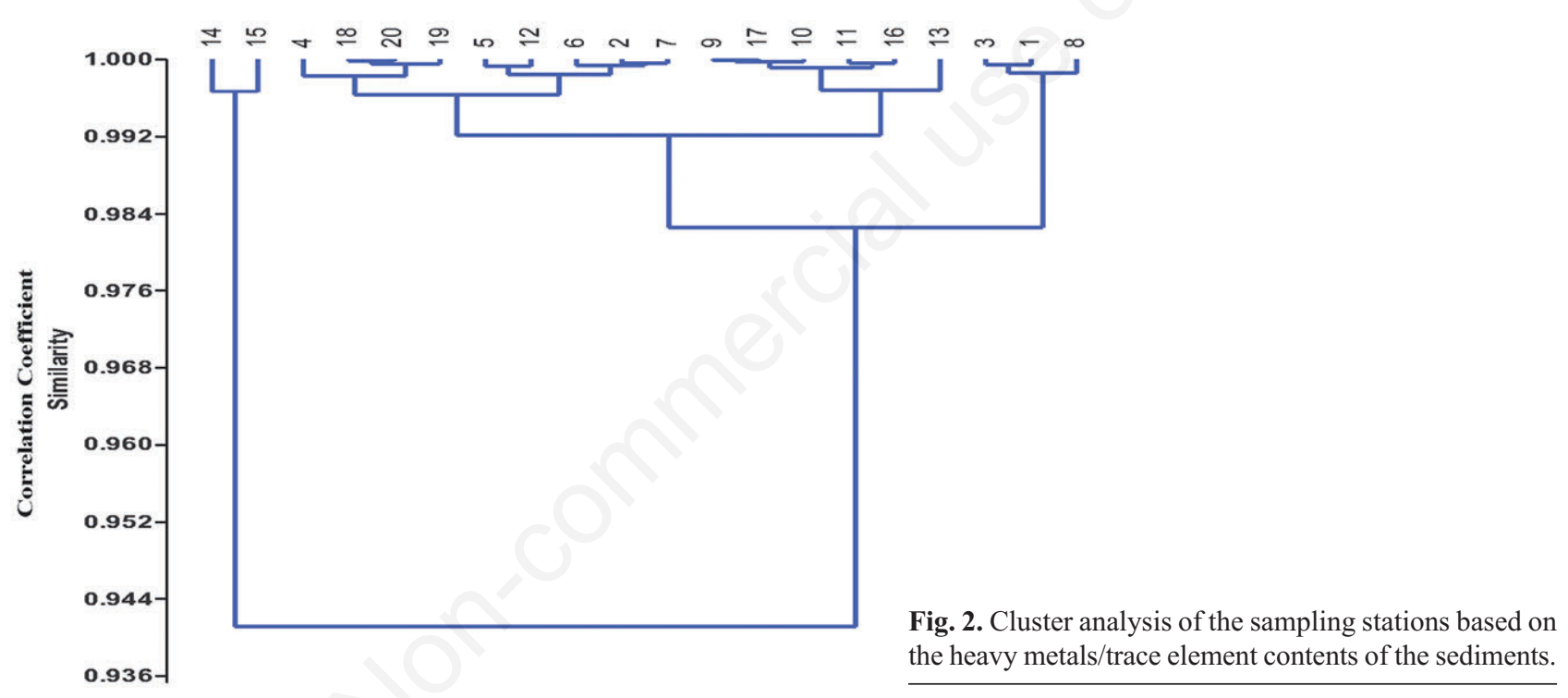

Tab. 6. Seasonal variations of heavy metals/trace elements concentrations in the sediments samples of Owalla Reservoir.

\begin{tabular}{|c|c|c|c|c|c|c|c|}
\hline \multirow[b]{3}{*}{$\mathbf{S} / \mathbf{N}$} & \multirow[b]{3}{*}{ Parameter } & \multirow[b]{3}{*}{ Unit } & \multirow[b]{3}{*}{$\mathbf{N}$} & \multicolumn{2}{|c|}{ Season } & \multicolumn{2}{|c|}{ ANOVA } \\
\hline & & & & Dry season & Rainy season & & \\
\hline & & & & Mean $\pm \mathrm{SE}$ & Mean $\pm \mathrm{SE}$ & F & $\mathbf{P}$ \\
\hline 1 & Arsenic (As) & $\mu \mathrm{g} \mathrm{g}^{-1}$ & 76 & $11.66 \pm 0.89$ & $12.46 \pm 0.36$ & 0.687 & 0.409 \\
\hline 2 & Cadmium (Cd) & $\mu \mathrm{g} \mathrm{g}^{-1}$ & 76 & $2.86 \pm 0.03$ & $2.93 \pm 0.02$ & 3.138 & 0.079 \\
\hline 3 & Cobalt (Co) & $\mu \mathrm{g} \mathrm{g}^{-1}$ & 76 & $6.97 \pm 0.36$ & $6.66 \pm 0.30$ & 0.419 & 0.518 \\
\hline 4 & Chromium $(\mathrm{Cr})$ & $\mu \mathrm{g} \mathrm{g}^{-1}$ & 76 & $3.96 \pm 0.24$ & $3.81 \pm 0.18$ & 0.276 & 0.600 \\
\hline 5 & Copper $(\mathrm{Cu})$ & $\mu \mathrm{g} \mathrm{g}^{-1}$ & 76 & $2.93 \pm 0.28$ & $3.46 \pm 0.47$ & 0.931 & 0.336 \\
\hline 6 & Iron $(\mathrm{Fe})$ & $\mu \mathrm{g} \mathrm{g}^{-1}$ & 76 & $179.93 \pm 6.51$ & $172.50 \pm 5.94$ & 0.711 & 0.400 \\
\hline 7 & Manganese (Mn) & $\mu \mathrm{g} \mathrm{g}^{-1}$ & 76 & $123.20 \pm 3.90$ & $117.72 \pm 4.47$ & 0.855 & 0.357 \\
\hline 8 & Nickel (Ni) & $\mu \mathrm{g} \mathrm{g}^{-1}$ & 76 & $6.55 \pm 0.36$ & $7.98 \pm 0.38$ & 7.646 & $0.006^{*}$ \\
\hline 9 & Lead $(\mathrm{Pb})$ & $\mu \mathrm{g} \mathrm{g}^{-1}$ & 76 & $2.92 \pm 0.29$ & $3.17 \pm 0.33$ & 0.333 & 0.565 \\
\hline 10 & Zinc $(\mathrm{Zn})$ & $\mu \mathrm{g} \mathrm{g}^{-1}$ & 76 & $8.55 \pm 1.05$ & $9.44 \pm 1.00$ & 0.372 & 0.543 \\
\hline
\end{tabular}

Degree of freedoms, between groups: 1 ; within groups: $150 ; * \mathrm{P} \leq 0.05$. 
wet or dry deposition and simultaneous oxidation and reconversion of arsenic to non-volatile forms (Chatterjee et al., 2017). As shown in this study, $\mathrm{Fe}$ and $\mathrm{Mn}$ in the sediments had concentrations about ten times higher than the other elements and both have been found to be naturally associated with arsenic occurrence in sediments.

Natural sources of cadmium from the area could be originated from parent rock materials, soil, plants, and animal matter sunk into the sediment through one or more natural processes like weathering, erosion, and decomposition in the area. According to Mislin and Ravera (1986), cadmium is found in varying amounts as a natural component of the surface environment in rocks, overburden and soils, water, air, plant and animal tissues with an average concentration in the earth's crust reported being between $0.15 \mu \mathrm{g} \mathrm{g}^{-1}$ and $0.11 \mu \mathrm{g} \mathrm{g}^{-1}$.

Anthropogenic sources of arsenic and cadmium from the area could come mainly from domestic and agricultural activities within the catchment basin, considering that subsistence agriculture has been the mainstay of more than $90 \%$ of the riparian population. Since the majority of the farmers in the area practice subsistence agriculture with no access to mechanized agriculture, the use of agro-chemicals to boost crop productions and protections is usually a common practice. As and $\mathrm{Cd}$ have been found in various concentrations in agro-chemicals used to boost (fertilizers, manures, etc.) and protect crop production (herbicides, pesticides, fungicides, rodenticides, etc.). For example, since the industrial revolution, the use of arsenic as an insecticide, fungicide, and herbicide gradually peaked in 1950s when it was one of the most common pesticides in use, because it was an inexpensive by-product of the smelting of copper, iron, silver, cobalt, nickel, lead, gold, zinc, manganese, and tin. Also, agricultural workers preferred to use arsenic and not lead because of its accumulative poison characteristics over insects and pests (Gupta, et al., 2017). Likewise, phosphate fertilizers and manures used to boost crop productions can contain varying amounts of cadmium (De Boo, 1990; Roberts, 2014), representing examples of anthropogenic sources of cadmium in the ecosystems. Arsenic is listed by the US Environmental Protection Agency (USEPA) as one of the priority pollutants and is listed among the most hazardous substances having a significant potential threat to human health (Gupta, et al., 2017). Arsenic, through ages, is being persistently regarded as a highprofile poison and was related to several conspicuous murder cases, for instance, in the infamous death of Napoleon Bonaparte in 1851, which was claimed to be a political murder by some conspiracy theorists (Gupta, et al., 2017). The U.S. Department of Health and the European Commission's Institute of Health and Consumer Protection have recently summarized the adverse health effects of cadmium on the kidney, renal cortex, pulmonary, cardiovascular, and musculoskeletal systems; moreover, $\mathrm{Cd}$ was reported as a human carcinogen. For example, cadmium poisoning known as Itai-itai disease, a disease causing softening of the bones and kidney failure, was originally discovered in association with rice cultivation in Asia (Roberts, 2014).

Concentrations of the heavy metals/trace elements did not follow any definite pattern from the upstream-downstream basin, although most of them showed significant difference in their horizontal variations. Further, the highest mean concentrations of the different metals were obtained in various basins of the reservoir. This could probably be explained by the different inputs of pollutants (domestic and agricultural) coming from local populations located within the different areas of the watershed (upstream, midbasin and downstream). This could also confirm that most of the current anthropogenic inputs of these elements into the sediment of the reservoir were mainly of domestic and agricultural sources. Most of the elements with significant horizontal variations are generally regarded as nutritional essential elements (i.e. $\mathrm{Co}, \mathrm{Cu}, \mathrm{Fe}, \mathrm{Mn}$, and $\mathrm{Zn}$ ). In this regard, heavy metals/trace elements have been grouped into toxic $(\mathrm{As}, \mathrm{Cd}, \mathrm{Hg}$, and $\mathrm{Pb})$ and nutritional essential $(\mathrm{Ca}$, $\mathrm{Co}, \mathrm{Cr}, \mathrm{Cu}, \mathrm{Fe}, \mathrm{Mn}, \mathrm{Mo}, \mathrm{Ni}, \mathrm{Se}$, and $\mathrm{Zn}$ ) elements by Alonso et al. (2004).

Most heavy metals (Co, Fe, Mn, Ni, $\mathrm{Pb}$, and $\mathrm{Zn}$ ) had significant higher mean values in the open water region than the littoral region of the reservoir. The occurrence of background concentrations of trace elements in soils and sediments is, besides the lithology, also influenced by their clay and organic matter content. Therefore, clay and organic matter content are often used to calculate 'corrected' background values for trace metal concentrations in soils and sediments (De-Saedeleer et al., 2010). Also, according to Parizanganeh (2008), the elemental concentration of sediments not only depend on anthropogenic and lithogenic sources, but also upon the textural characteristics, hydrogen ion concentration $(\mathrm{pH})$, organic matter content, mineralogical composition and depositional environments of sediments. It is generally believed that metals are associated with smaller grain-size particles. Therefore, in this study, the higher concentrations of the heavy metals in the open water region could be due to the higher clay and organic matter content that characterizes this area compared to the littoral region. Moreover, the peripheral shallow areas are subject to fluctuating temperatures and erosion of shore materials through wave action. The result is a coastline region of relatively coarse sediment, especially evident near unprotected shores (Cole, 1975).

Increased acidity tends to dissolve and mobilize heavy metals/trace elements in sediments, causing an increase of concentrations in lake water. The hydrogen ion concentration of sediments in the open water zone is usually higher because this stratum of water is generally characterized by decay rather than the production of organic 
matter. The sediments in central zones are fine particles largely made up of materials produced within the lake (Cole, 1975). As suggested by Parizanganeh (2008), the open water region also represents the depositional environment where most of the suspended materials in the water column are usually deposited, whereas the littoral is the eroding region where the action of water movements drags most suspended particles towards the deep stable and less disturbed region.

Most of the heavy metals/trace elements from the reservoir did not show significant seasonal difference. This could be explained considering that the concentrations of the heavy metals/trace elements in the sediments from this study were the result of the long-term accumulations of these elements over a long period of time rather than fresh anthropogenic enrichments from influx of allochthonous materials due to high incidences of flooding and erosions during the rainy season.

\section{CONCLUSIONS}

The overall hierarchy of concentrations of heavy metals/trace elements in the reservoir sediment samples based on the mean values was in the decreasing order: $\mathrm{Fe}>\mathrm{Mn}$ $>\mathrm{As}>\mathrm{Zn}>\mathrm{Ni}>\mathrm{Co}>\mathrm{Cr}>\mathrm{Cu}>\mathrm{Pb}>\mathrm{Cd}$. The concentrations of the heavy metals did not follow any definite common pattern from the upstream-downstream basin, although most of them $(\mathrm{Cu}, \mathrm{Fe}, \mathrm{Mn}, \mathrm{Zn}$ and $\mathrm{Co})$ showed significant differences in their horizontal variations, but with various different spatial gradients and highest values in different areas of the reservoir. These unpredictable patterns are an indication that the populations living along the shores in different areas of the watershed might have produced different amounts and types of pollutants (domestic and agricultural sources) discharged to the reservoir. Many heavy metal/trace elements analyzed from the sediment samples $(\mathrm{Mn}, \mathrm{Pb}, \mathrm{Co}, \mathrm{Fe}$, $\mathrm{Ni}$, and $\mathrm{Zn}$ ) showed higher mean values at the open water region than in the littoral region. Except Ni, all the heavy $\mathrm{metal} /$ trace elements did not show significant seasonal difference in their mean values across the dry and rainy seasons. With the exception of As and Cd, most of the elements in the sediments showed concentrations within the background levels defined in environmental regulations and guidelines. $\mathrm{C}_{\mathrm{f}}$ values of the different metals from the sediment samples indicated a low sediment contamination with $\mathrm{Co}, \mathrm{Cr}, \mathrm{Cu}, \mathrm{Fe}, \mathrm{Mn}, \mathrm{Ni}, \mathrm{Pb}$, and $\mathrm{Zn}\left(\mathrm{C}_{\mathrm{f}}<1.0\right)$. Conversely, sediments were moderately contaminated with $\mathrm{Cd}\left(\mathrm{C}_{\mathrm{f}}=2.41\right)$ and very highly contaminated with $A s\left(C_{\mathrm{f}}=19.33\right)$.

\section{ACKNOWLEDGMENTS}

The authors wish to acknowledge the contribution of Mr. Adebayo Amubieya and Godwin Zach for their as- sistance during the field collection. We are grateful to two anonymous reviewers and the Editor for valuable comments and suggestions on an earlier version of the manuscript.

\section{REFERENCES}

Adeyemo OK, Adedokun OA, Yusuf RK, Adeleye EA, 2008. Seasonal changes in physicochemical parameters and nutrient load of river sediments in Ibadan City, Nigeria. Glob. NEST J. 10:326-336.

Agboola SA, 1979. An agricultural atlas of Nigeria. Oxford University Press, Oxford: 248 pp.

Akot O, Abankwa E, 2014. Heavy metals contamination and speciation in sediments of the Owabi Reservoir. Environ. Res. J. 8:10-16.

Alloway BJ, Ayres DC, 1997. Chemical principles of environmental pollution. $2^{\text {nd }}$ ed. Chapman and Hall, London: 302 pp.

Alonso ML, Montaña FP, Miranda M, Castillo C, Hernandez J, Benedito JL, 2004. Interactions between toxic (As, Cd, Hg, and $\mathrm{Pb}$ ) and nutritional essential $(\mathrm{Ca}, \mathrm{Co}, \mathrm{Cr}, \mathrm{Cu}, \mathrm{Fe}, \mathrm{Mn}$, $\mathrm{Mo}, \mathrm{Ni}, \mathrm{Se}, \mathrm{Zn}$ ) elements in the tissues of cattle from NW Spain. BioMetals 17:389-397.

APHA, 1995. Standard methods for the examination of water and wastewater. $19^{\text {th }}$ ed. APHA, AWWA, WEF, Washington: 1220 pages.

Asibor IG, 2008. The macroinvertebrate fauna and sediment characteristics of Asejire Reservoir, Southwest, Nigeria. Ph.D. Thesis, Obafemi Awolowo University, Ile-Ife.

BCMECCS (British Columbia Ministry of Environment and Climate Change Strategy), 2017. Environmental Quality Standards. Available from: https://www2.gov.bc.ca/gov/content/environment/air-land-water/site-remediation/ guidanceresources/technical guidance

Birch G, Siaka M, Owens C, 2001. The source of anthropogenic heavy metals in fluvial sediments of a rural catchment: Cox River, Australia. Water Air Soil Pollut. 126:13-35.

Bonai NC, Souza-Franco G M, Fogolari O, Mocelin DJC., Dal Magro J, 2009. Distribution of metals in the sediment of the Itá Reservoir, Brazil. Acta Limnol. Bras. 21245-250.

Burton AG, 2002. Sediment quality criteria in use around the world. Limnology 3:65-75.

Chatterjee S, Moogoui R, Gupta DK, 2017. Arsenic: Source, occurrence, cycle, and detection, p. 14-29 In: D.K. Gupta and S. Chatterjee (eds.), Arsenic contamination in the environment-The issues and solutions. Springer, Cham.

Cole GA, 1975. Textbook of limnology. The C.V. Mosby Co., Saint Louis: 283 pp.

Davies OA, Abowei JFN, 2009. Sediment quality of lower reaches of Okpoka Creek, Niger Delta, Nigeria. Eur. J. Sci. Res. 26:437-442.

De Boo W, 1990. Cadmium in agriculture. Toxicol. Environ. Chem. 27:55-63.

Decena SCP, Arguilles MS, Robel LL, 2018. Assessing heavy metal contamination in surface sediments in an urban river in the Philippines. Pol. J. Environ. Stud. 27:1983-1995.

De-Saedeleer V, Cappuyns V, De-Cooman W, Swennen R, 2010. Influence of major elements on the heavy metal composition of river sediments. Geologica Belgica 13:257-268. 
Duffus JH, 2002. "Heavy metal"- a meaningless term? Pure Appl. Chem. 74:793-807.

Dung TTT, Cappuyns V, Swennen R, Phung NK, 2013. From geochemical background determination to pollution assessment of heavy metals in sediments and soils. Rev. Environ. Sci. Bio/Technol. 12:335-353.

Environmental Statement for Port of Southampton (ESPS), 2015. Sediment Quality: Southampton approach Chanel Dredge, p. 107-121. In: Report R/3742/8/R.2015. Marine and Environment Research, ABPmer.

Ezekiel EN, Hart AI, Abowei JFN, 2011. The sediment physical and chemical characteristics in Sombreiro River, Niger Delta, Nigeria. Res. J. Environ. Earth Sci. 3:341-349.

Faboya OL, Sojinu OS, Sonibare OO, 2012. An assessment of heavy metals contamination in surface sediments of the Niger Delta, Nigeria. Can. J. Pure Appl. Sci. 6:2169-2174.

Filho FJ, Marins RV, de Lacerda LD, Aguiar JE, Peres TF, 2015. Background values for evaluation of heavy metal contamination in sediments in the Parnaíba River Delta estuary, NE/Brazil. Mar. Pollut. Bull. 91:424-428.

Gautam RK, Sharma SK, Mahiya S, Chattopadhyaya MC, 2015. Metals in aquatic media: Transport, toxicity and technologies for remediation, p. 1-24. In: S.K. Sharma (ed.), Heavy metals in water, presence, removal and safety. Royal Society of Chemistry, Cambridge.

Goher ME, Farhat HI, Abdo MH, Salem SG, 2014. Metal pollution assessment in the surface sediment of Lake Nasser, Egypt. Egyp. J. Aquat. Res. 40:213-224.

Gupta DK, Tiwari S, Razafindrabe BHN, Chatterjee S, 2017. Arsenic contamination from historical aspects to the present, p.1-10. In: D.K. Gupta and S. Chatterjee (eds.), Arsenic contamination in the environment-The issues and solutions. Springer, Cham.

International Atomic Energy Agency, 2003. Collection and preparation of bottom sediment samples for analysis of radionuclides and trace elements. IAEA-TECDOC-1360. International Atomic Energy Agency, Vienna: 130 pp.

Jahangir TM, Khuhawar MY, Leghari SM, Mahar MT, Mahar KP, 2014. Water quality and sediment assessment of Manchar Lake, Sindh, Pakistan: after effects of the super flood of 2010. Arab. J. Geosci. 8:3259-3283.

Kavitha P, Kumar SP, 2013. Evaluation and sediment quality assessment of two perennial ponds in Kanyakumari District, Tamil Nadu, South India. Int. J. Res. Environ. Sci. Technol. 3:135-144.

Keay RWJ, 1959. An outline of Nigerian vegetation. $3^{\text {rd }}$ ed. Government Printer, Nigeria: 46 pp.

Kogbe CA, 1976. Geology of Nigeria. University of Life Center for Advanced Studies. Elizabethan Publishing Co., Lagos: $436 \mathrm{pp}$.

Lasheen MR, 1987. The distribution of trace metals in Aswan High Dam Reservoir and River Nile ecosystems, p. 235-254 In: T.C. Hutchinson and K.M. Meema (eds.), Lead, mercury, cadmium, and arsenic in the environment. J. Wiley \& Sons, Chichester.

Li F, Huang J, Zeng G, Yuan X, Li X, Liang J, Wang X, Tang X, Bai B, 2013. Spatial risk assessment and sources identification of heavy metals in surface sediments from Dongting Lake, Middle China. J. Geochem. Explor. 132:75-83.

Machiwa JF, 2003. Metal Concentrations in sediments and Fish of Lake Victoria, near and away from catchments with gold mining activities. Tanz. J. Sci. 29:43-54.

Martin JM, Whitefield M, 1983. The significance of the river input of chemical elements to the ocean, p. 265-296. In: C.S. Wong, E. Boyle, K.W. Bruland and E.D. Goldberg (eds.), Trace metals in seawater. Plenum Press, New York.

Mislin H, Ravera O, 1986. Cadmium in the environment. Birkhäuser Verlag, Basel: 144 pp.

Morgantini N, Peruzzi L, 2014. Surface sediment quality in Trasimeno Lake. Proceedings of $15^{\text {th }}$ World Lake Conference, Perugia, Italy.

Nathaniel IT, 2002. The Macro-invertebrate benthic fauna and bottom sediment studies of Opa Reservoir. M.Phil. Thesis, Zoology Department, Obafemi Awolowo University.

Nzeve JK, Kitur EC, Njuguna SG, 2014. Determination of heavy metals in sediments of Masinga Reservoir, Kenya. J. Environ. Earth Sci. 4:125-132.

Ogunkoya OO, 2013. 'All rivers run into the sea, yet the sea is not full...' Obafemi Awolowo University Inaugural Lecture Series 256: $61 \mathrm{pp}$.

Ojo O, 1977. The climates of West Africa. Heinemann Educational Books, Ibadan: $219 \mathrm{pp}$.

Oladejo SO, Ofoezie IE, 2006. Unabated schistosomiasis transmission in Erinle River Dam, Osun State, Nigeria: evidence of neglect of environmental effects of development projects. Trop. Medi. Int. Health 11:843-850.

Olutona GO, Aribisala OG, Akintunde EA, 2012. A study of chemical speciation of metals in the aquatic bottom sediment of Aiba reservoir, Iwo, Nigeria. Afr. J. Environ. Sci. Technol. 6:312-321.

Parizanganeh A, 2008. Grain size effects on trace metals in contaminated sediments along the Iranian coast of the Caspian Sea, p. 329-336. In: M. Sengupta and R. Dalwani (eds.), Proceedings of the 12th World Lake Conference.

Podlasińska J, Szydłowski K, 2017. Assessment of heavy metal pollution in bottom sediments of small water reservoirs with different catchment management. Pol. Acad. Sci. 3:987-997.

Rahaman MA, 1976. A review of the basement geology of South Western Nigeria, p. 41-58. In: C.A. Kogbe (ed.), Geology of Nigeria. Elizabethan Publication Co., Lagos.

Rahaman MA, Ocan O, 1978. On relationships in the Precambrian migmatite-Gneisses of Nigeria. J. Mining Geol. 15:23-30.

Raulinaitis M, Ignatavičius G, Sinkevičius S, Oškinis V, 2012. Assessment of heavy metal contamination and spatial distribution in surface and subsurface sediment layers in the northern part of Lake Babrukas. Ekologija 58:33-43.

Roberts TL, 2014. Cadmium and phosphorous fertilizers: The issues and the science. Procedia Engin. 83:52-59.

Saha PK, Hossain MD, 2011. Assessment of heavy metal contamination and sediment quality in the Buriganga River, Bangladesh, p. 384-388. Proceedings 2nd Int. Conf. on Environmental Science and Technology. IACSIT Press, Singapore.

Skordas K, Kelepertzis E, Kosmidis D, Panagiotaki P, Vafidis D, 2015. Assessment of nutrients and heavy metals in the surface sediments of the artificial lake water reservoir Karla, Thessaly, Greece. Environ Earth Sc. 73:4483-4493.

Smedley PL, Kinniburgh DG, 2002. A review of the source, behaviour and distribution of arsenic in natural waters. Appl. Geochem. 17:517-568.

Smedley PL, Kinniburgh DG, 2015. Source and behaviour of 
arsenic in natural waters. British Geological Survey Report: $61 \mathrm{pp}$.

Smyth AJ, Montgomery FR, 1962. Soil and land use in Central Western Nigeria. The Government Printer, Ibadan: 265 pp.

Szarek-Gwiazda E, Mazurkiewicz-Boroń G, Gwiazda R, Urban J, 2018. Chemical variability of water and sediment over time and along a mountain river subjected to natural and human impact. Knowl. Manag. Aquat. Ec. 419:1-14.

Taylor SR, 1964. Abundance of chemical elements in the continental crust: a new table. Geochim. Cosmochim. Acta 28:1273-1285.

Tijani MN, Onodera S, 2009. Hydrogeochemical assessment of metals contamination in an urban drainage system: A case study of Osogbo Township, South-West, Nigeria. J. Water Resour. Protect. 1:164-173.

Todorovic ZB, Randelovic LM, Marjanovic JZ, Todorovic VM,
Cakic MD, Cvetkovic OG, 2014. The assessment and distribution of heavy metals in surface sediments from the reservoir "Barje" (Serbia). Adv. Technol. 3:85-95.

Turekian, KK, Wedepohl KH, 1961. Distribution of the elements in some major units of the earth' crust. Geol. Soc. Am. Bull. 72:175-192.

Ugbomoiko US, Ofoezie IE, 2007. Multiple infection diagnoses of intestinal helminthiasis in the assessment of health and environmental effect of development projects in Nigeria. J. Helminthol. 81:227-231.

US Environmental Protection Agency, 1999. Screening level ecological risk assessment protocol for hazardous waste combustion facilities. Appendix E: Toxicity reference values. Solid Waste and Emergency Response. Report EPA530D99-001C. Available from: www.epa.gov/osw 